\title{
SEASONAL DYNAMICS OF ORGANIC CARBON AND NITROGEN IN BIOMASSES OF MICROORGANISMS AFFECTED BY DIFFERENT TILLAGE SYSTEMS
}

Y.S. Kravchenko ${ }^{1 *}$, Zhang Xingyi ${ }^{2}$, Song Chun-yu ${ }^{2}$, A.V.Yarosh ${ }^{1}$, O.V.Voitsekhivska ${ }^{3}$

${ }^{1}$ National University of Life and Environmental Sciences of Ukraine, 15, Heroyiv Oborony Str., Kyiv, Ukraine, 03041, kravch@i.ua* (for correspondence), +380674931657,yaroshanna@ukr.net,

${ }^{2}$ Northeast institute of geography and agricultural ecology, the Chines Academy of Science, 138 Harping RD, Harbin, P.R.China, 150081, zhangxy@iga.ac.cn, cys@iga.ac.cn

Voitsekhivska Olena Vasylivna

${ }^{3}$ Taras Shevchenko National University of Kyiv, Institute of Biology and Medicine, Volodymyrska st., 64/13, Kyiv, 01601, Ukraine, matushka@i.ua, +380679084758, https://orcid.org/0000-00026983-5781

The main purpose of this study was to determine the size and direction of the seasonal dynamics of organic carbon $\left(\mathrm{C}_{\text {micro }}\right)$ and nitrogen $\left(\mathrm{N}_{\text {micro }}\right)$ biomass of microorganisms and microbial index $\left(\mathrm{C}_{\text {micro }}: \mathrm{C}_{\text {org }}\right)$ of natural and agrocenoses with their different uses. Field research methods involved taking of soil samples in 0-10-, 10-20- and 20-40 cm layers. Under laboratory conditions, the content of total soil carbon was determined by dry oxygen combustion on a Vario EL III analyzer (Elementar Analyzensysteme, Hanau, Germany). The carbon content of microbial biomass $\left(\mathrm{C}_{\text {micro }}\right)$ was determined by chloroform fumigation extraction method (CFE). To freshly taken soil samples (2 hours) and soil samples after their 24-hour fumigation with chloroform vapors, $0.5 \mathrm{M} \mathrm{K} 2 \mathrm{SO} 4$ was added to extract biomass lysis products of soil microorganisms. The content of organic carbon and nitrogen in the biomass of microorganisms in the obtained filtrates was determined on the Elementar Liqui TOC II, Analyzensysteme GmbH, Germany. The carbon content of microbial biomass was calculated from the difference between carbon in fumigated and control samples using a factor of 0,45 - for carbon and 0,54 - for nitrogen. The microbial index of soils was determined by the ratio between the carbon of microorganisms and the total organic carbon of the soil $-\mathrm{C}_{\text {micro }}: \mathrm{C}_{\text {org }} \bullet 100(\%)$. Average values and confidence intervals were determined for each defined indicator. The Bonferoni method was used to correct the errors of multiple comparative samples of a one-way ANOVA analyze. K. Pearson's linear correlation analysis was used to establish the relationships between the dynamics of carbon biomass of microorganisms and organic carbon of the soil during the growing season. Our research has shown the dynamics of $\mathrm{C}_{\text {micro }}, \mathrm{N}_{\text {micro }}, \mathrm{C}_{\text {micro }}: \mathrm{N}_{\text {micro }}$ and $\mathrm{C}_{\text {micro }}$ : $\mathrm{C}_{\text {org }}$ during the growing season. Analysis of the box plot showed the largest amplitude of $\mathrm{C}_{\text {micro }}$ changes in the upper 
0-10 cm layer of izogumusol. The smallest difference in the quartile range $\left(\mathrm{IQR}_{0,25}\right.$ 0,75 ) was for no-till and overhang (Ab) in the upper 0-10-, no-till (NT) and fallow (F) in the layer 10-20- and plowing (CT) - in a layer of $20-40 \mathrm{~cm}$. The content of organic carbon biomass of microorganisms in the upper layer of izogumusol at the beginning of the growing season had the highest values of $\mathrm{Ab}(577,79 \pm 1,64 \mathrm{mg} / \mathrm{kg})$, NT $(485,43 \pm 1,97 \mathrm{mg} / \mathrm{kg})$ and CT $(470,43 \pm 0,77 \mathrm{mg} / \mathrm{kg})$, the smallest - for F $(370,15 \pm$ $2,18 \mathrm{mg} / \mathrm{kg}$ ). The content of $\mathrm{N}_{\text {micro }}$ during this period decreased from Ab to Comb (combined tillage), NT, CT, Rot (rotary tillage), RT (reduced (ridge) tillage) and F, respectively. In the $20-40 \mathrm{~cm}$ layer, the highest values of $\mathrm{C}_{\text {micro }}$ and $\mathrm{N}_{\text {micro }}$ were observed in mid-July. The lowest values of $\mathrm{C}_{\text {micro }}$ and $\mathrm{N}_{\text {micro }}$ and the largest $-\mathrm{C}_{\text {micro }}$ : $\mathrm{N}_{\text {micro }}$ were found in late August for all variants and layers of the study. The dynamics of the microbial index resembled the trends of $\mathrm{C}_{\text {micro }}$ and $\mathrm{N}_{\text {micro. }}$. The largest share of Smicro in Sorghum during the growing season, on average was: - Ab $(1,82 \pm 1,85 \%)$ and NT $(1,66 \pm 1,52 \%)$ - in the layer 0-10-, - Ab $(1,23 \pm 1,27 \%)$ and NT $(1,29 \pm$ $1,32 \%)$ - in the layer 10-20- and - Ab (1,19 $\pm 1,09 \%)$ and F $(1,11 \pm 1,077 \%)$ - in a layer of 20-40 cm. Different use of izogumusol affected the amplitude of seasonal changes of $\mathrm{C}_{\text {micro }}$ and $\mathrm{N}_{\text {micro }}$ and did not affect on their direction. The maximum content of $\mathrm{C}_{\text {micro }}$ and $\mathrm{N}_{\text {micro }}$ was observed at the beginning of the growing season - in a layer of 0-10 cm and in mid-July - in a layer of 20-40 cm, the minimum - at the end of the summer period. During this period, the widest ratio of $\mathrm{C}_{\text {micro }}: \mathrm{N}_{\text {micro }}$ was for $\mathrm{F}$ and CT - in the layer 0-20 cm and CT and Rot - in the layer 20-40 cm. The Pearson's correlation coefficient between $\mathrm{C}_{\text {micro }}$ and $\mathrm{C}_{\text {org }}$ increased from the upper 0-10- to the lower 20-40 cm layer of izogumusol. "Strong" and "high" negative correlations have been established between $\mathrm{C}_{\text {micro }}$ and $\mathrm{C}_{\text {org }}$, but no pattern has been found between the correlation coefficient and tillage technologies.

Key words: organic soil carbon, seasonal dynamics, biomass of microorganisms, organic nitrogen, tillage, microbial index

Introduction. Microbial biomass (MB) is part of the living phase of the soil, the content of which in most soils is in the range from 1-5 to $10 \%$ of soil organic matter weight $[1,2]$. Study of the biomass dynamics of microorganisms showed that the average life expectancy for $35 \%$ and $65 \%$ of soil bacteria is 7 months and 14 years, respectively [3]. Bacteria and archeobacteria are most active in the rhizosphere of the soil, which is saturated with $0.8 \mathrm{~mm}$ or more of soil pores, while mycorrhizal fungi are concentrated mainly near plant precipitation, forest litter or steppe felt [4]. F. Cotrufo et al. [5] it's believed that the amount of organic soil substrate, which is transformed by microorganisms is the main indicator that characterizes the dynamics of soil organic matter.

Given the rapid cycle (from several days to weeks) of labile microbial biomass [6], its dynamics precede changes in the content of organic carbon, nitrogen and sulfur in soils, thus acting as a primary indicator of changes in arable soil properties or their recovery processes or degradation $[7,8]$. The dynamics of microorganism`s biomass and soil organic matter can be indirectly assessed by the magnitude of $\mathrm{CO}_{2}$ 
release in agrocenoses. According to Hamilton S. et al. [9] from 1 hectare of field (crop rotation consisted of corn for grain and soybeans) 4.2 tons of $\mathrm{CO} 2$ were released per year, of which $29 \%$ - produced bacteria, $31 \%$ - fungi, $10 \%$ - fauna and $30 \%$ - the root system of plants. A number of authors [10,11] propose to apply the parameters of soil microbial biomass when assessing the soil quality. The content of microbial biomass, as part of the soil organic matter, increases with the improvement of soil quality, with the introduction of manure, crop residues, the introduction of legumes in crop rotation, the use of soil protection technologies, etc. [12]. At the same time, we still do not have a complete understanding of how the synthesis and stabilization of bio-molecules in soils with the participation of microorganisms occur [5].

Seasonal changes in the biomass of microorganisms depend primarily on soil temperature and water potential, content of labile humic substances and biophilic elements, quantity and quality of dead plant substrate, ORP regime and physicochemical properties of soils [13]. The introduction of intensive technologies in the cultivation of crops changes the regimes and properties of soils, thus affecting the content and dynamics of microorganism`s biomass. Reduced (ridge) tillage technologies improve soil quality, increase the content of organic compounds of carbon and nitrogen in the surface layers of soils, thus initiating the accelerated growth of biomass and activity of microorganisms in these layers [14]. By no-till, organic plant residues accumulates near the earth's surface creating a trophic layer of food for fungi and microorganisms [15]. The dominance of fungi over bacteria is found in the layer of 0-5 cm [16]. Bacteria, according to B. Nicolardot et al. [17], are the main destructor of the plant substrate incorporated into the soil using traditional plowing. B. Helgason et al. [18], noted a simultaneous increase in the number of biomass of microorganisms and fungi by no-till with a short-term predominance of fungal biomass over bacteria. This effect has been observed in soil samples of pastures and forest ecosystems explain the predominance of fungal biomass over microorganisms by no-till features of the analytical method for the determination of fatty acid phospholipids (PLFAs) in the above organisms [19, 20, 21].

According to S. Thiessen et al. [22], the humification coefficient depends on the biomass of microorganisms, the size of which in mineral soils with a small number of microorganisms is larger than in organic soils with a large number of microorganisms [23]. According to other data [24], the same amplitude of growth of soil organic carbon content was observed in soils with different levels of microorganism`s biomass. According to J. Rousk et al. [25] there is no direct relationship between the size of microbial biomass and organic soil carbon. The influence of microbiological activity on the formation of specific humic substances is determined by a set of interrelated factors, which include: the content of labile forms of nitrogen, the qualitative composition of plant residues, abiotic climatic parameters, etc. [26]. Therefore, the mechanism of microorganism`s biomass influence on the formation of organic carbon of humic substances is determined by both natural and anthropogenic factors and is still not fully disclosed. The object of this work is to determine the direction and size of the seasonal dynamics of organic carbon and nitrogen biomass of microorganisms in natural and agrocenoses. 
Materials and methods. The object of study was selected: izogumusol in Heilongjiang Province (China). International analogues of Chinese chernozem are: Haoplic-Luvic Phaeozems, Haplic Chernozems, Udoll Mollisols (USA) [27], leached blacksoil (Ukraine, Russia). The studied Chinese soil is characterized by a transitional "ustic" - "udic" moisture regime.

Field experimental research was conducted during 2010-2016, at the National Research Station for Research of Agroecosystems Hailun. The station is located on the outskirts of Hailun City, Heilongjiang Province $\left(47^{\circ} 126^{\prime} \mathrm{N}, 126^{\circ} 38^{\prime} \mathrm{E}\right)$ which is a structural unit of the Northeastern Institute of Geography and Agroecology of the National Academy of Sciences of China. The field stationary one-factor experiment was established in 2004 by the method of randomized plots with the size of the elementary plot 8.4 x $40=336 \mathrm{~m}^{2}$, the test plot $-100 \mathrm{~m}^{2}$. The experiment was repeated three times.

The system of basic tillage was represented by: conservation tillage (CT) to a depth of 27-30 cm, reduced (ridge) tillage (RT) with chisel comber to a depth of 25 $\mathrm{cm}$, no-till (NT), combined tillage (Comb) with a rotary comb depth of $30 \mathrm{~cm}$, rotary tillage (Rot) with a rotary comb-forming to a depth of $20 \mathrm{~cm}$. Soil under 22-year-old abandoned field $(\mathrm{Ab})$ and 22-year-old fallow $(\mathrm{F})$ were also studied. The crop rotation scheme in the short-rotation crop rotation consisted of two crops: soybeans and corn for grain. Of the mineral fertilizers used: urea, triple superphosphate and potassium sulfate. The norms of mineral fertilizers were: $\mathrm{N}_{69,5} \mathrm{P}_{51,75} \mathrm{~K}_{15}+\mathrm{N}_{100}\left(\mathrm{CO}\left(\mathrm{NH}_{2}\right)_{2}\right)$ - for corn for grain and $\mathrm{N}_{20,25} \mathrm{P}_{51,75} \mathrm{~K}_{15}$ - for soybeans. Soil samples were taken from 0-10-, 10-20- and 20-40 cm layers.

Dry burning (elemental analysis) was used to determine the organic carbon content and total soil nitrogen [28]. Air-dry soil (10-15 g) with removed plant remains was ground in an agate mortar, sifted through a sieve with holes of $0,25 \mathrm{~mm}$, re-selected small organic residues with tweezers and electrostatically charged ebonite stick, the cleaned sample was poured into the "shuttle" (capsule), from which $20 \mathrm{mg}$ of sample was taken for analysis. Weighing was performed directly on the scales in an aluminum box, which after weighing was closed with an envelope and twisted, after which the sample was placed in an automatic sampler, from which it came to dry oxygen combustion at a temperature of $600-650{ }^{\circ} \mathrm{C}$ on the device Vario EL III analyzer [28]. (Elementar Analyzensysteme, Hanau, Germany).

The carbon content of microbial biomass $\left(\mathrm{C}_{\text {micro }}\right)$ was determined by the chloroform fumigation extraction method (CFE). This method involves the extraction of $0,5 \mathrm{M} \mathrm{K}_{2} \mathrm{SO}_{4}$ with a solution of lysis products of biomass of soil microorganisms that died after 24 hours of fumigation with chloroform vapor [29, 30]. Fresh soil samples taken no earlier than 2 hours before the start of the analysis were used for this study. Fresh soil, from which 2 soil samples of $40 \mathrm{~g}$ each were taken, was sieved through a sieve with $2 \mathrm{~mm}$ holes, and plant residues and non-soil material were removed. Each soil sample was examined for field moisture content. A soil sample intended for fumigation was transferred to an open $100 \mathrm{ml}$ beaker and placed in a desiccator. At the bottom, in the central part of the desiccator, were laid out: - wet paper (to prevent drying of the soil during fumigation); - $50 \mathrm{ml}$ of $10 \mathrm{~mol} / \mathrm{l} \mathrm{NaOH}$ solution in a glass of $100 \mathrm{ml}$; - $40 \mathrm{ml}$ of chloroform (which does not contain ethanol) 
in a $100 \mathrm{ml}$ beaker with small pieces of glass (to prevent the formation of large bubbles of chloroform). The desiccator was lubricated with vaseline, covered with a ground lid (without air bubbles at the joint), and then the air was pumped out with a vacuum compressor until the chloroform began to boil. Boiling was continued for 1-2 minutes, after which the desiccator tap was closed and after 2 minutes the desiccator was placed for 24 hours in a thermostat with a constant temperature of $+25{ }^{\circ} \mathrm{C}$. A day later, under the hood, opened the tap, launched atmospheric air, and then opened the lid of the desiccator. Control and fumigated soil samples were transferred to a 250 $\mathrm{ml}$ flask to which $150 \mathrm{ml}$ of $0,5 \mathrm{M} \mathrm{K}_{2} \mathrm{SO}_{4}$ solution was added. The resulting suspension was shaken for 30 minutes on a rotator. The saline solution of the electrolyte - coagulator $\left(0,5 \mathrm{M} \mathrm{K}_{2} \mathrm{SO}_{4}\right)$ after the rotator was filtered into plastic bottles, closed with a lid and placed in the refrigerator for daily storage at a temperature of $+4{ }^{\circ} \mathrm{C}$ or in the freezer - for long-term storage. The content of organic carbon $\left(\mathrm{C}_{\text {micro }}\right)$ and nitrogen $\left(\mathrm{N}_{\text {micro }}\right)$ biomass of microorganisms in the obtained filtrates was determined on the device Elementar Liqui TOC II, Analyzensysteme $\mathrm{GmbH}$, Germany. The carbon content of microbial biomass was calculated by the difference between carbon in fumigated and control samples using a factor of $0,45-$ for carbon and $0,54-$ for nitrogen [31, 32, 33, 34].

The arithmetic mean of the results, the variance estimate, the reliable probability $(p=0.95)$, the significant difference and the level of reliability of the results were determined using software Microsoft Excel 2016, IBM SPSS Statistics for Windows v. 20.0, SigmaPlot for Windows Version 14.0. Average values and standard deviations were determined for each defined indicator. Student's t-test at the significance level $\alpha=0,05$ was used to compare the average values. The confidence interval $\alpha=0,01$ was calculated by comparing sets of values that characterized the seasonal dynamics of organic carbon of soils and microorganisms. The Bonferoni method was used to correct the errors of multiple comparative samples of one-way analysis of variance (a one-way ANOVA analyze).

\section{Results.}

The size of the amplitude of the seasonal dynamics of organic carbon and nitrogen biomass of microorganisms depended on the nature of the use of izogumusol and the depth of soil sampling. The largest amplitude of seasonal changes of $\mathrm{C}_{\text {micro }}$ was observed in soil samples of the upper 0-10 cm layer of izogumusol (Fig. 1A), the smallest - in the layer of 10-20 cm (Fig. 1B). The largest values of the third quartile $\mathrm{Xn}$. $(0,75)$ were observed for $\mathrm{Ab}$ in all soil layers. The smallest values of the first quartile Xn. $(0,25)$ were for $F$ in the layer $0-20 \mathrm{~cm}$ and Rot - in the layer $20-40 \mathrm{~cm}$ (Fig. 1C). The largest difference in the quartile scale $\left(\mathrm{IQR}_{0,25-0,75}\right)$ was observed for $\mathrm{CT}$ in the layer $0-20 \mathrm{~cm}$ and $\mathrm{RT}-$ in the layer $20-40 \mathrm{~cm}$. Maximum quartile amplitude of $\mathrm{C}_{\text {micro }}$ values in the range $\mathrm{IQR}_{0,10-0,90}$ was found for CT and Rot - in the layer 0-10 cm, Ab and CT - in the layer 10-20 cm and RT and Comb - in the layer 20$40 \mathrm{~cm}$. The medians, within the quartile range (IQR), tended to the lower position, thus creating a lower asymmetry of the box (boxplot). The lower position of the median indicates a tendency to decrease the amplitude of the dynamics of $\mathrm{C}_{\text {micro }}$ during the growing season.

The carbon content of microorganism`s biomass gradually decreased in 0-10- 
and increased - in 10-40 cm layers from May $16(203,08-577,79 \mathrm{mg} / \mathrm{kg})$ to August 23 $(191,29-470,02 \mathrm{mg} / \mathrm{kg})$ and increased in early October $(207,42-518,09 \mathrm{mg} / \mathrm{kg})$ (Fig. 2 ). The dynamics curve $\mathrm{N}_{\text {micro }}$ repeated the trend of $\mathrm{C}_{\text {micro }}$ : the maximum nitrogen content of microorganism`s biomass accumulated in the spring, gradually decreased until August and resumed in October (Fig. 3). The high amplitude of fluctuations in the biomass of microorganisms indicates less resistance of microbial coenoses to environmental factors. The largest amplitude of seasonal changes $\mathrm{N}_{\text {micro }}$ in $0-10-, 10$ 20- and 20-40 cm layers of arable soils was observed for: CT $-9,218 \pm 7,98 \mathrm{mg} / \mathrm{kg}$, Comb $-4,317 \pm 4,67 \mathrm{mg} / \mathrm{kg}$ and $\mathrm{Rot}-2,23 \pm 4,32 \mathrm{mg} / \mathrm{kg}$. The ratio of $\mathrm{C}_{\text {micro }}: \mathrm{N}_{\text {micro }}$ in arable soils increased rapidly from July 12 to August 23 and had the highest peak in 0-10-, 10-20- and 20-40 cm layers by CT $(10,10 \pm 0,81 \%)$, CT $(10,88 \pm 1,11 \%)$ and Rot (12,54 $\pm 1,41 \%$ ) (Fig. 4). On average per season, the highest value of the ratio $\mathrm{C}_{\text {micro }}$ : $\mathrm{N}_{\text {micro }}$ was observed for F, CT and Rot, the lowest - for Ab and NT.

\section{Discussion}

Seasonal changes in the biomass of microorganisms, which is determined by the method of fumigation-extraction, can occur 2-4 or more times [35, 36, 37]. Moreover, with agricultural use of soils, the seasonal dynamics of microorganism`s biomass is more pronounced compared to natural coenoses [38].

\section{1}

According to the results of our research, the content of organic carbon and nitrogen changed during the season: the highest content of $\mathrm{C}_{\text {micro }}$ and $\mathrm{N}_{\text {micro }}$ was observed in mid May-July, decreased by the end of August and recovered in October (Fig. 2 - 3). This pattern was observed in the izogumusol of Northeast China [39, 40]. The speed of microbial circulation in soils, in addition to abiotic factors, is also affected by the presence of readily available humic substances, detritus, colloid desorption products and transformation of plant residues, plant root system secretions, products of hydrolysis of organic polymers, etc. [41]. At the beginning of the growing season, the average daily air temperature was $+18{ }^{\circ} \mathrm{C}$, the studied izogumusol had a soil temperature - $\mathrm{t} \approx 19-23{ }^{\circ} \mathrm{C}$ - in a layer of $0-5 \mathrm{~cm}$ and $10-14{ }^{\circ} \mathrm{C}$ in a layer of 10-20 cm, arable layer of soil was well moistened ( $\mathrm{W}=20,4-27,7 \%)$, it contained numerous remains of the predecessor plant - soybeans and newly formed in the autumn-winter period labile humic substances. Izogumusol at this time was enriched with mineral forms of nutrients due to the introduction in late April - early May of the main seed mineral fertilizer at the rate of $\mathrm{N}_{69,5} \mathrm{P}_{51,75} \mathrm{~K}_{15}$, followed by two feedings of urea $\mathrm{N}_{50}+\mathrm{N}_{50}$. The presence of organic matter available for mineralization led to the initialization of the hydrolytic microflora (L-strategists), which prepared for other groups of microorganisms easily hydrolyzed substrate [42]. It was during this period that the so-called priming effect took place, which stimulated the metabolic activity of microorganisms in izogumusols [43]. As a result, in mid May, the highest content of $\mathrm{C}_{\text {micro }}$ and $\mathrm{N}_{\text {micro }}$ was observed in the $0-10 \mathrm{~cm}$ layer of soil in all studied variants. The highest values of $\mathrm{C}_{\text {micro }}$ and $\mathrm{N}_{\text {micro }}$ in this period were found for: $\mathrm{Ab}(577,79 \pm 1,64-$ and $65,0 \pm 0,47 \mathrm{mg} / \mathrm{kg})$, NT $(485,43 \pm 1,97$ - and $52,7 \pm 0,45 \mathrm{mg} / \mathrm{kg}$ ). The lowest content of organic carbon and nitrogen was observed 
for black fallow. During the next two weeks after the onset of the seed effect, the biomass of microorganisms stabilizes, decreases in early June and gradually increases until mid July, which is primarily associated with increased rainfall, root and mycorrhizal secretions, rising soil temperature and moisture.

For NT and Ab, the temperature of the top layer of izogumusol during the season was slightly lower compared to the studied options of tillage due to the presence of living and dead vegetation and higher moisture content. This effect led to a prolonged succession of decomposing natural amino and polysaccharides of soil microorganisms under the above options. According to the results of our studies, for NT and Ab during the study period there was no short-term hotspot [44] outbreak of microorganisms during the growing season. This can be explained by the increasing activity of mycorrhizal fungi on plant remains, and the lack of significant changes in temperature and soil moisture in izogumusol, which is associated with rising air temperatures and monsoon climate during the growing season. S. Frey et al. [45, 46] and O. Butenschoen [16] noted a significant predominance of fungal to bacterial biomass by no-till. The results obtained by X. Jiang et al. [47] indicate the local placing of fungal biomass in macroaggregates and biomass of microorganisms - in soil microaggregates, regardless of the method of tillage. S. Cleveland and D. Liptzin [48] believe that the high ratio of $\mathrm{C}_{\text {micro }}: \mathrm{N}_{\text {micro }}$ in soil macroaggregates by CT compared to NT, indicates insufficient nitrogen content during plowing. According to the results of our research, which are confirmed by the work of Hernández and Lopez-Hernández [49], for CT $(26,49-29,79 \mathrm{mg} / \mathrm{kg})$ and F $(23,52-27,21 \mathrm{mg} / \mathrm{kg})$, on average for season, the lowest amount of nitrogen accumulated in the biomass of microorganisms, which led to the widest ratio of $\mathrm{C}_{\text {micro }}: \mathrm{N}_{\text {micro }}$ by rotational treatment $(11,49 \pm 1,41)$ and black fallow $(11,43 \pm 1,09)$ (Fig. 4).

During August, the total amount of easily soluble organic substrate, nutrients and moisture available to plants decreased, the density and soil temperature increased, the ORP regime was characterized by maximum oxidation, tillage and movement of agricultural machinery in the field during the season led to the destruction of structural units. As a result of microorganisms utilization of organic plant residues, fungal exudates and plant root system, easily soluble low molecular weight humic substances, the nutrient substrate is reduced, which leads to a decrease in the quantitative and species composition of microorganisms. There is competition between plants and microorganisms for available nutrients. All the above factors contributed to the largest decrease in the concentration of biomass of soil microorganisms in late August. In early October, before harvesting, nutrients are reutilized into the soil, the amount of plant precipitation increases, which against the background of more rainfall and the average daily air temperature $+12{ }^{\circ} \mathrm{C}$, increased the biomass of microorganisms in izogumusol. During the cold period of the year, the ratio of fungal biomass to bacteria increases. At this time, micellar and yeast fungi, actinomycetes, which are deep destructors of sparingly soluble heat-resistant compounds such as cellulose and lignin, are actively developing [50, 51]. Due to the above-mentioned organisms, in the spring, before the beginning of the growing season, a significant amount of labile and nonspecific humic substances accumulate in the soil, which are actively used by microorganisms and plants during the growing 
season.

To establish the relationship between the change in carbon of microorganism's biomass and the dynamics of organic carbon of the soil during the growing season, we conducted a correlation analysis and determined the coefficients of linear correlation of K. Pearson (Table 1). It was found that the positive correlation between the two parameters increased from the upper $0-10 \mathrm{~cm}$ layer to the lower $-20-40 \mathrm{~cm}$ layer. The value of the correlation coefficient between $C_{\text {micro }}$ and $C_{\text {org }}$ in the $0-10 \mathrm{~cm}$ layer of Hailun izogumusol according to the "Chaddock Table" is estimated mainly as: "moderate" and "significant". "Strong" (0,70-0,89) and single "high" (0,90-0,99) negative correlations in Hailun izogumusol were found between: $\mathrm{F}_{\text {org }}$ and $\mathrm{RT} \mathrm{C}_{\text {micro, }}$, $\mathrm{Ab} \mathrm{C}_{\text {micro }}$ and $\mathrm{F} \mathrm{C}_{\text {org }}$, Rot $\mathrm{C}_{\text {org }}$ and $\mathrm{RT} \mathrm{C}_{\text {micro }}$, Comb $\mathrm{C}_{\text {org }}$ and Comb $\mathrm{C}_{\text {micro }}-$ in $0-10 \mathrm{~cm}$ layer, $\mathrm{NT} \mathrm{C}_{\text {micro }}$ and $\mathrm{CT} \mathrm{C}_{\text {org }}, \mathrm{F} \mathrm{C}_{\text {org }}$, Comb $\mathrm{C}_{\text {org }}$ and Rot $\mathrm{C}_{\text {org }}$; $\mathrm{CT}_{\mathrm{C}_{\text {micro }}}$ and Comb $\mathrm{C}_{\text {org }}$ and Rot $\mathrm{C}_{\text {org }} ; \mathrm{F}_{\text {micro }}$ and Comb $\mathrm{C}_{\text {org }}$ and Rot $\mathrm{C}_{\text {org }}$; Rot $\mathrm{C}_{\text {org }}$ and $\mathrm{Comb}_{\text {org }}-$ in 10-20 cm layer; RT $\mathrm{C}_{\text {micro }}$ and $\mathrm{CT} \mathrm{C}_{\text {org }}, \mathrm{Ab} \mathrm{C}_{\text {org }}$ and Rot $\mathrm{C}_{\text {org }}$; $\mathrm{RT} \mathrm{C}_{\text {micro }}$ and NT $\mathrm{C}_{\text {org }}$, CT $\mathrm{C}_{\text {org }}, \mathrm{Ab} \mathrm{C}_{\text {org }}$ and Rot $\mathrm{C}_{\text {org }}, \mathrm{F} \mathrm{C}_{\text {micro }}$ and $\mathrm{RT} \mathrm{C}_{\text {org }}, \mathrm{Comb}_{\mathrm{C}_{\text {micro }}}$ and $\mathrm{CT}_{\text {org }}$ and Rot $\mathrm{C}_{\text {org }}$; Rot $\mathrm{C}_{\text {micro }}$ and $\mathrm{NT} \mathrm{C}_{\text {org }}, \mathrm{CT} \mathrm{C}_{\text {org }}, \mathrm{Ab} \mathrm{C}_{\text {org }}$, Comb $\mathrm{C}_{\text {org }}$ and Rot $\mathrm{C}_{\text {org }}-$ in 20-40 cm layer.

Microbial index of soils $\left(\mathrm{C}_{\text {micro }} / \mathrm{C}_{\text {org }}\right) \cdot 100(\%)$ is a sensitive indicator used in the study of primary changes in the qualitative composition of organic matter against the background of changes in soil properties [52]. The proportion of $\mathrm{C}_{\text {micro }}: \mathrm{C}_{\text {org }}$ increases as a result of active conversion of soil organic matter by soil microorganisms and decreases in degraded soils. The microbial index (MI) of soils increases in light well-moistened weakly acid soils of natural grass cenoses [53]. According to the results of our research, MI during the growing season varied from $0,72 \pm 0,168$ - to $2,00 \pm 0,030 \%$ (Fig. 5). The value of MI during the growing season varied similarly to the dynamics of $\mathrm{C}_{\text {micro }}$ and $\mathrm{N}_{\text {micro }}$. The microbial index decreased from the beginning of the growing season to the end of August and increased in early October. The highest values of MI in the 0-20 cm layer were observed for Ab and NT in Hailun izogumusols. In the lower 20-40 cm layer of izogumusol, MI was predominant by $\mathrm{Ab}, \mathrm{F}$ and $\mathrm{CT}$. During the intensive growth and development of plants, most of the labile carbon of microorganisms in the humus was formed by $\mathrm{Ab}$, NT and F (in the layer of 20-40 cm). RT occupied the middle position among other options in terms of microbial index. At the beginning of October, MI increased with all tillage technologies and agrocenoses. The microbial index gradually decreased with depth.

\section{Conclusions.}

- The maximum content of organic carbon and nitrogen in the biomass of microorganisms was observed in mid May, mid July and early October.

- The highest content of $\mathrm{C}_{\text {micro }}$ and $\mathrm{N}_{\text {micro }}$ in izogumusol on average per season was observed for fallow, and among tillage technologies for: no-till - in 0-20 $\mathrm{cm}$ layer, and Comb - in layer $20-40 \mathrm{~cm}$.

- The smallest amplitude of seasonal changes of $\mathrm{C}_{\text {micro }}$ in 0-10-, 10-20- and 20$40 \mathrm{~cm}$ layers was observed for Comb, NT and CT. 
- The highest value of the ratio $C_{\text {micro }}: N_{\text {micro }}$ during the growing season was observed in late August. This index increased with depth. The smallest values of the ratio $\mathrm{C}_{\text {micro }}: \mathrm{N}_{\text {micro }}$ were observed for $\mathrm{Ab}$ and Comb - in the layer 0-10 $\mathrm{cm}$ and NT - in the layer $10-40 \mathrm{~cm}$.

- The highest values of the microbial index in the 0-20 cm layer were observed for fallow and no-till. In the lower 20-40 cm layer of izogumusol, MI was predominant by $\mathrm{Ab}, \mathrm{F}$ and $\mathrm{CT}$.

\section{Compliance with ethical standards.}

The work was performed at the Institute of Geography and Agroecology of the National Academy of Sciences of China under the grants received: № GJHZ0949 from the Bureau of International Cooperation of the Chinese Academy of Sciences and № 41171230 of the National Science Foundation.

Field and laboratory studies were performed without the involvement of animals.

\section{Conflict of Interest}

The authors declare that there are no conflicts of interest.

\section{References}

1. Dalal, R., Soil microbial biomass - what do the numbers really mean? Australian Journal of Experimental Agriculture, 1998,38: 649-665.

2. Jenkinson, D.S., Ladd, J.N., Microbial biomass in soil: Measurement and turnover. Biochemistry, 1991, 5, 415-471.

3. Paul, E.A., Follett, R.F., Haddix, M., Preussner E., Soil N dynamics related to soil C and microbial changes during long-term incubation. Soil Sci., 2011, 176, 527-536.

4. Fry, S., The spatial distribution of soil biota. In: Paul E. (Ed.) Soil Microbiology, Ecology and Biochemistry, fourth ed. Academic Press, San Diego, 2015, 223-244.

5. Cotrufo, F., Wallenstein, M., Denef K., et al. The molecular efficiency-matrix stabilization (MEMS) framework integrates plant litter decomposition with soil organic matter stabilization. Glob Change Biol., 2013, 19: 988-995.

6. Schmidt, S.K., Costello, E.K., Nemergut, D.R., et al. Biogeochemical consequences of rapid microbial turnover and seasonal succession in soil. Ecology, 2007, 88 (6), 1379-1385.

7. Powlson, D.S., Jenkinson, D.S. A comparison of the organic matter, biomass, adenosine triphosphate and mineralizable nitrogen contents of ploughed and direct-drilled soils. J. Agric. Sci., 1981, 97, 713-721.

8. Moklyachuk, L., Yatsuk, I., Draga, M. Monitoring study of Soil Fertility in the Agricultural Area of Rivne Region of Ukraine. Emirates Journal of Food and Agriculture, 2015, 7(2), 221-230.

9. Hamilton SK, Doll JE, Robertson GP (2015) The Ecology of Agricultural Landscapes: Longterm Research on the Path to Sustainability. Oxford University Press, New York

10. Karlen, D.L., Mausbach, M.J., Doran, J.W. Soil quality: a concept, definition, and framework for evaluation. Soil Sci. Soc. Am. J., 1997, 61: 4-10.

11. Powlson, D.S., Brookes, P.C., Christensen, B.T. et al., Measurement of soil microbial biomass provides an early indication of changes in total soil organic matter due to straw incorporation. Soil Biol. Biochem., 1987, 19: 159-164.

12. Anderson, J.F., Domsch, K.H. Quantities of plant nutrients in the microbial biomass of selected soils. Soil Sci., 1980, 130, 211-216.

13. Holmes, W., Zak, R. Soil Microbial Biomass Dynamics and Net Nitrogen Mineralization in Northern Hardwood Ecosystems. Soil Sci. Soc. Am. J., 1994, 58, 238-243.

14. Wright, A.L., Hons, F.M., Lemon, R.G. Microbial activity and soil C sequestration for 
reduced and conventional tillage cotton. Applied Soil Ecology, 2008, 38, 168-173.

15. Helgason, B.L., Walley, F.L., Germida, J.J. Fungal and bacterial abundance in long-term notill and intensive-till soils of the northern great plains. Soil Science Society of America Journal, 2009. 73, 120-127.

16. Butenschoen, O., Poll, C., Langel, R. Endogeic earthworms alter carbon translocation by fungi at the soil-litter interface. Soil Biology and Biochemistry, 2007, 39, 2854-2864.

17. Nicolardot, B., Bouziri, L., Bastian, F. et. al. A microcosm experiment to evaluate the influence of location and quality of plant residues on residue decomposition and genetic structure of soil microbial communities. Soil Biology and Biochemistry, 2007, 39, 1631-1644.

18. Helgason, B.L., Walley, F.L., Germida, J.J. et. al. Fungal and bacterial abundance in longterm no-till and intensive-till soils of the Northern Great Plains. Soil Science Society of America Journal, 2009, 73, 120-127.

19. Demoling, F., Nilsson, L., Baath, E. et. al. Bacterial and fungal response to nitrogen fertilization in three coniferous forest soils. Soil Biology and Biochemistry, 2008, 40, 370-379.

20. de Vries, F.T., Hoffland, E., van Eekeren, N. et. al. Fungal bacterial ratios in grasslands with contrasting nitrogen management. Soil Biology and Biochemistry, 2006, 38, 2092-2103.

21. Bailey, V.L., Smith, J.L., Bolton, H. et. al. Fungal: bacterial ratios in soils investigated for enhanced C sequestration. Soil Biology and Biochemistry, 2002, 34, 997-1007.

22. Thiessen, S., Gleixner, G., Wutzler, T. et. al. Both priming and temperature sensitivity of soil organic matter decomposition depend on microbial biomass - an incubation study. Soil Biology and Biochemistry, 2013, 57, 739-748.

23. Wang, $\mathrm{H}$., $\mathrm{Xu}, \mathrm{W} ., \mathrm{Hu}, \mathrm{G}$. et. al. The priming effect of soluble carbon inputs in organic and mineral soils from a temperate forest. Oecologia, 2015, 178, 1239-1250.

24. Murphy, C.J., Baggs, E.M., Morley, N. et. al. Rhizosphere priming can promote mobilisation of N-rich compounds from soil organic matter. Soil Biology and Biochemistry, 2015, 81, 236-243.

25. Rousk, J., Hill, P., Jones, D. et. al. Priming of the decomposition of ageing soil organic matter: concentration dependence and microbial control. Functional Ecology, 2015, 29, 285-296.

26. Shahbaz, M., Kuzyakov, Y., Heitkamp, F. et. al. Decrease of soil organic matter stabilization with increasing inputs: mechanisms and controls. Geoderma, 2017, 304, 76-82.

27. Soil Survey Staff. Illustrated guide to soil taxonomy: Version 1.1. Lincoln, Nebraska: 2015, USDA-NRCS.

28. ДСТУ ISO 10694-2001 Якість грунту. Визначання вмісту органічного і загального вуглецю методом сухого спалювання (елементний аналіз) (ISO 10694:1995, IDT). К.: Держспоживстандарт України, 2003.

29. Vance, E.D., Brookes, P.C., Jenkinson, D.S. et. al. An extraction method for measuring soil microbial biomass C. Soil Biology \& Biochemistry, 1987, 19, 703-707.

30. Voroney, R., Winter, J., Beyaert, R. et. al. Soil microbial biomass C and N. In: Carter MR (ed): Soil sampling and methods of analysis, Canadian Society of Soil Science, Lewis, Chelsea, 1993, 277-286.

31. Wu, J., Joergensen, R.G., Pommering, B. et. al. Measurement of soil microbial biomass C - an automated procedure. Soil Biology Biochemistry, 1990, 22, 1167-1169.

32. Brookes, P., Landman, A., Pruden, G. et. al. Chloroform fumigation and the release of soil nitrogen: a rapid direct extraction method to measure microbial biomass nitrogen in soil. Soil Biology Biochemistry, 1985, 17, 837-842.

33. Jenkinson, D.S. The determination of microbial biomass carbon and nitrogen in soil. In: Wilson J.R. (ed.): Advances in Nitrogen Cycling in Agricultural Ecosystems, CAB International, Wallingford, 1988, 368-386.

34. Mueller, T., Jensen, L., Nielsen, N. et. al. Turnover of carbon and nitrogen in a sandy loam soil following incorporation of chopped maize plants, barley straw and blue grass in the field. Soil Biology Biochemistry, 1998, 30, 561-571.

35. Devi, N.B., Yadava, P.S. Seasonal dynamics in soil microbial biomass C, N and P in a mixedoak forest ecosystem of Manipur, North-east India. Appl. Soil Ecol., 2006, 31 (3), 220-227. 
36. Edwards, K.A., Jefferies, R.L. Inter-annual and seasonal dynamics of soil microbial biomass and nutrients in wet and dry low-Arctic sedge meadows. Soil Biol. Biochem., 2013, 57, 83-90.

37. Чернова, Т.И., Железова, А.Д. Динамика микробных сообществ почвы в различных диапазонах времени (обзор). Почвоведение, 2020, 5, 590-600.

38. Lauber, C.L., Ramirez, K.S., Aanderud, Z. et. al. Temporal variability in soil microbial communities across land-use types. ISME J, 2013, 7 (8), 1641-1650.

39. Sui, Y., Xiao-guang, J., Chong-sheng, G. et. al. The Relationship among Organic Matter Content and Soil Microbial Biomass and Soil Enzyme Activityies. Chinese Journal of Soil Science, 2009, 40 (5), 1036-1039.

40. Lou, Y., Xu, M., Wang, W. et. al. Return rate of straw residue affects soil organic C sequestration by chemical fertilization. Soil Till Res, 2011, 113, 70-73.

41. McGill, W., Cannon, K.R., Robertson, J.A. Dynamics of Soil Microbial Biomass and WaterSoluble Organic C in Breton L After 50 Years of Cropping to Two Rotations. Canadian Journal of Soil Science, 1986, 66 (1), 1-19.

42. Чимитдоржиева, Э.О., Чимитдоржиева, Г.Д. Динамика углерода микробной биомассы целинных степных и сухостепных почв Забайкалья. Вестник КГУ им. Н.А. Некрасова, 2012, 3, 16-20.

43. Fontaine, S., Mariotti, A., Abbadie, L. et. al. The priming effect of organic matter: a question of microbial competition? Soil Biol. Biochem, 2003, 35 (6), 837-843.

44. Kuhnert, R., Oberkofler, I., Peintner, U. et. al. Fungal growth and biomass development is boosted by plants in snow-covered soil. Microbial Ecology, 2012, 64(1), 79-90.

45. Frey, S.D., Frey, S.D., Elliot, E.T. et. al. Bacterial and fungal abundance and biomass in conventional and no-tillage agroecosystems along two climatic gradients. Soil Biology and Biochemistry, 1999, 31, 573-585.

46. Frey, S.D., Six, J., Elliott, E.T. et. al. Reciprocal transfer of carbon and nitrogen by decomposer fungi at the soil-litter interface. Soil Biology and Biochemistry, 2003, 35, 1001-1004.

47. Jiang, X., Alan, L., Wright, X. et. al. Tillage-induced changes in fungal and bacterial biomass associated with soil aggregates: A long-term field study in a subtropical rice soil in China. Applied Soil Ecology, 2011, 48, 168-173.

48. Cleveland, C.C., Liptzin, D. C:N:P stoichiometry in soils: is there a "Redfield ratio" for the microbial biomass? Biogeochemistry, 2007, 85, 235-252.

49. Hernández-Hernández, R.M., Lopez-Hernández, D. Microbial biomass, mineral nitrogen and carbon content in savanna soil aggregates under conventional and no-tillage. Soil Biology and Biochemistry, 2002, 34, 1563-1570.

50. Kuhnert, R., Oberkofler, I., Peintner, U. Fungal growth and biomass development is boosted by plants in snow-covered soil. Microbial Ecology, 2012, 64(1), 79-90.

51. Schadt, C.W., Martin, A.P., Lipson, D.A. et. al. Seasonal dynamics of previously unknown fungal lineages in tundra soils. Science, 2003, 301(5638), 1359-1361.

52. Anderson, T.-H., Domsch, K.H. Ratio of microbial biomass carbon to total organic carbon in arable soils. Soil Biol. Biochem, 1989, 21, 471-479.

53. Sparling, G.P. Ratio of microbial biomass carbon to soil organic carbon as a sensitive indicator of changes in soil organic matter. Australian Journal of Soil Research, 1992, 30, 195-207. 

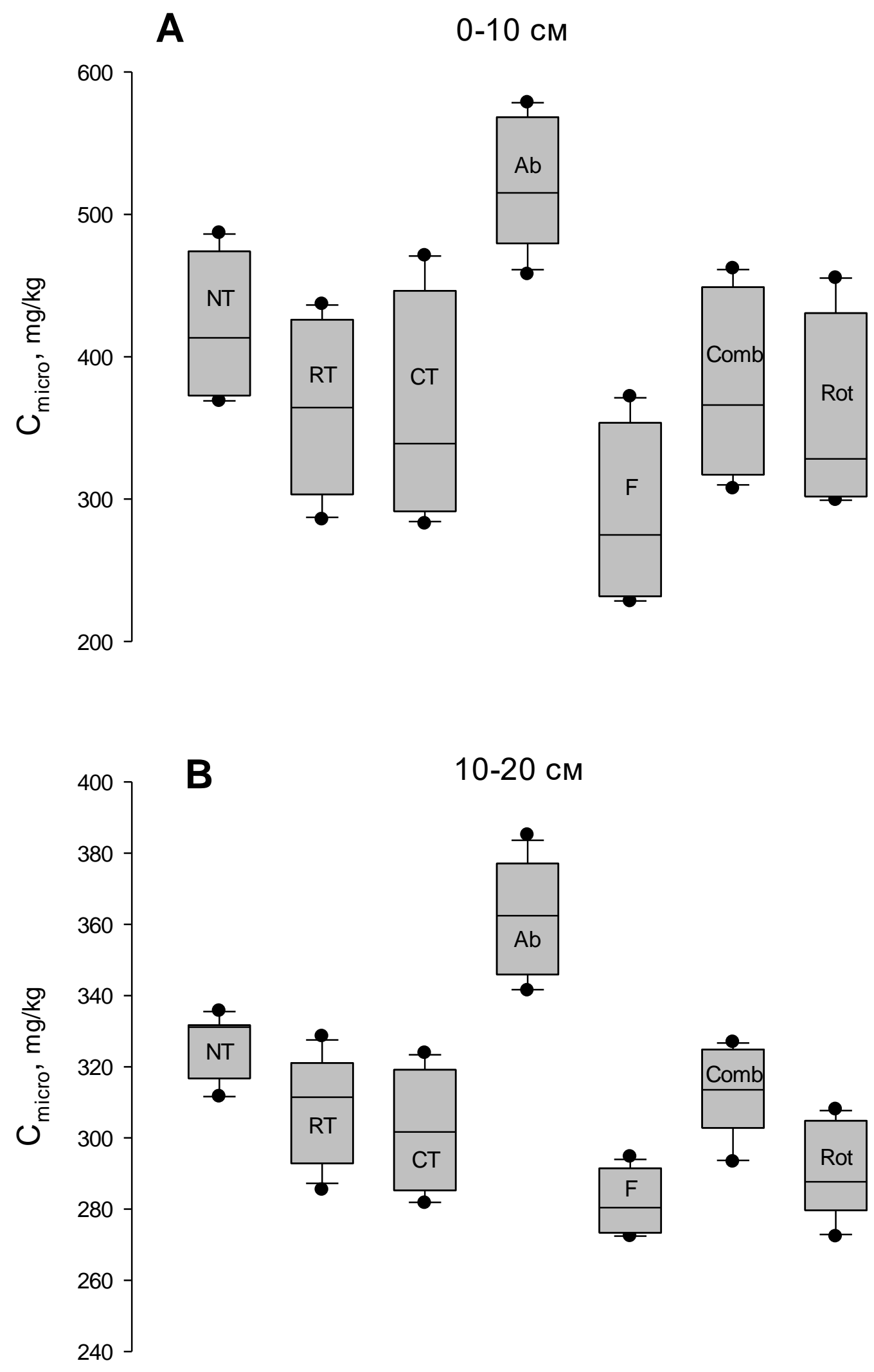


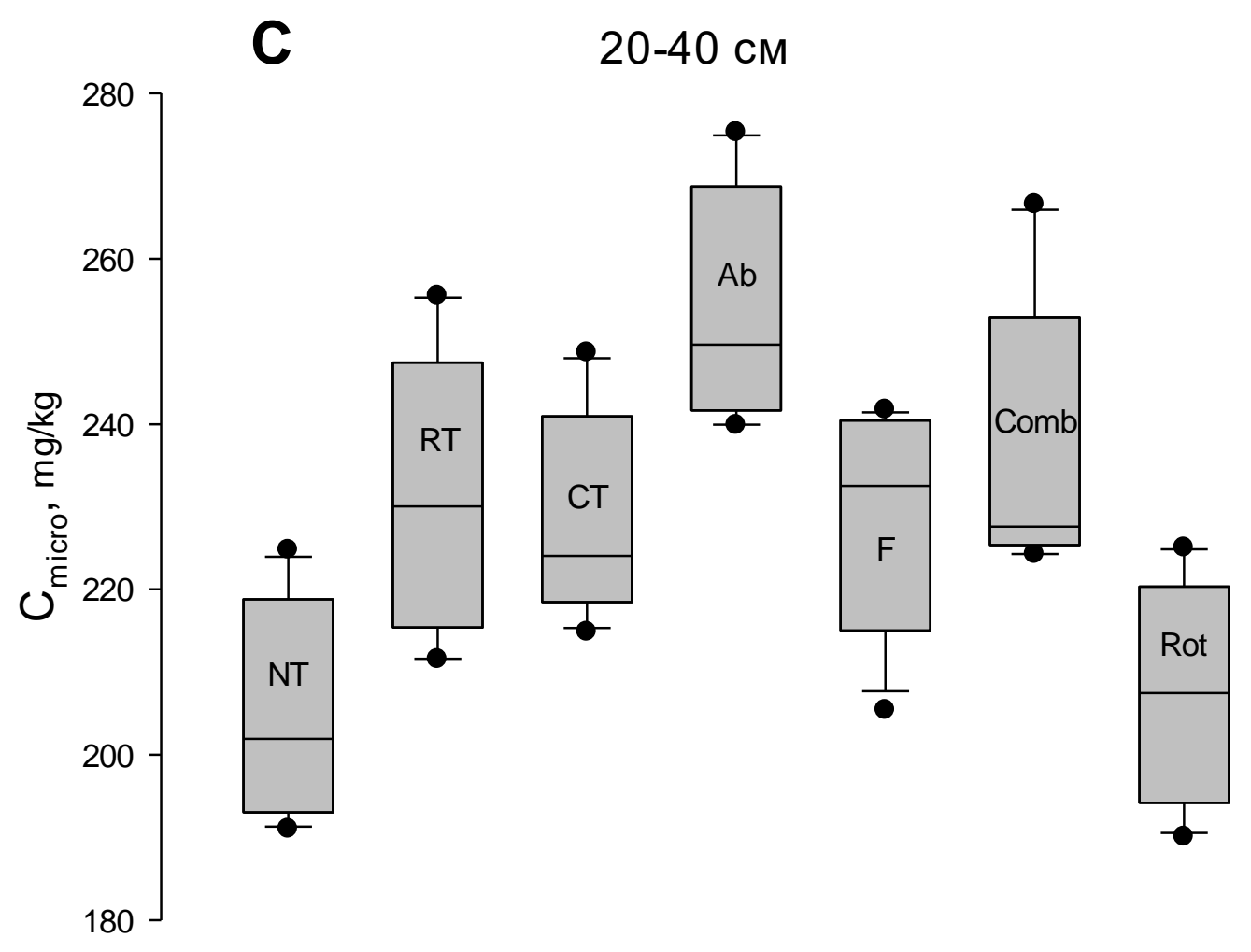

Fig. 1. Sizes of seasonal dynamics (box plot 25-75\%, median, $\mathrm{n}=12$, MayJuly-August-October) $\mathrm{C}_{\text {micro }}$ in 0-10 (A), 10-20 (B) and 20-40 cm layers of Hailun izogumusol under use: conservation tillage $(\mathrm{CT})$, no-till (NT), reduced (ridge) tillage $(\mathrm{RT})$, rotary (Rot), combined (Comb) tillage, fallow (F) and abandoned field (Ab) 

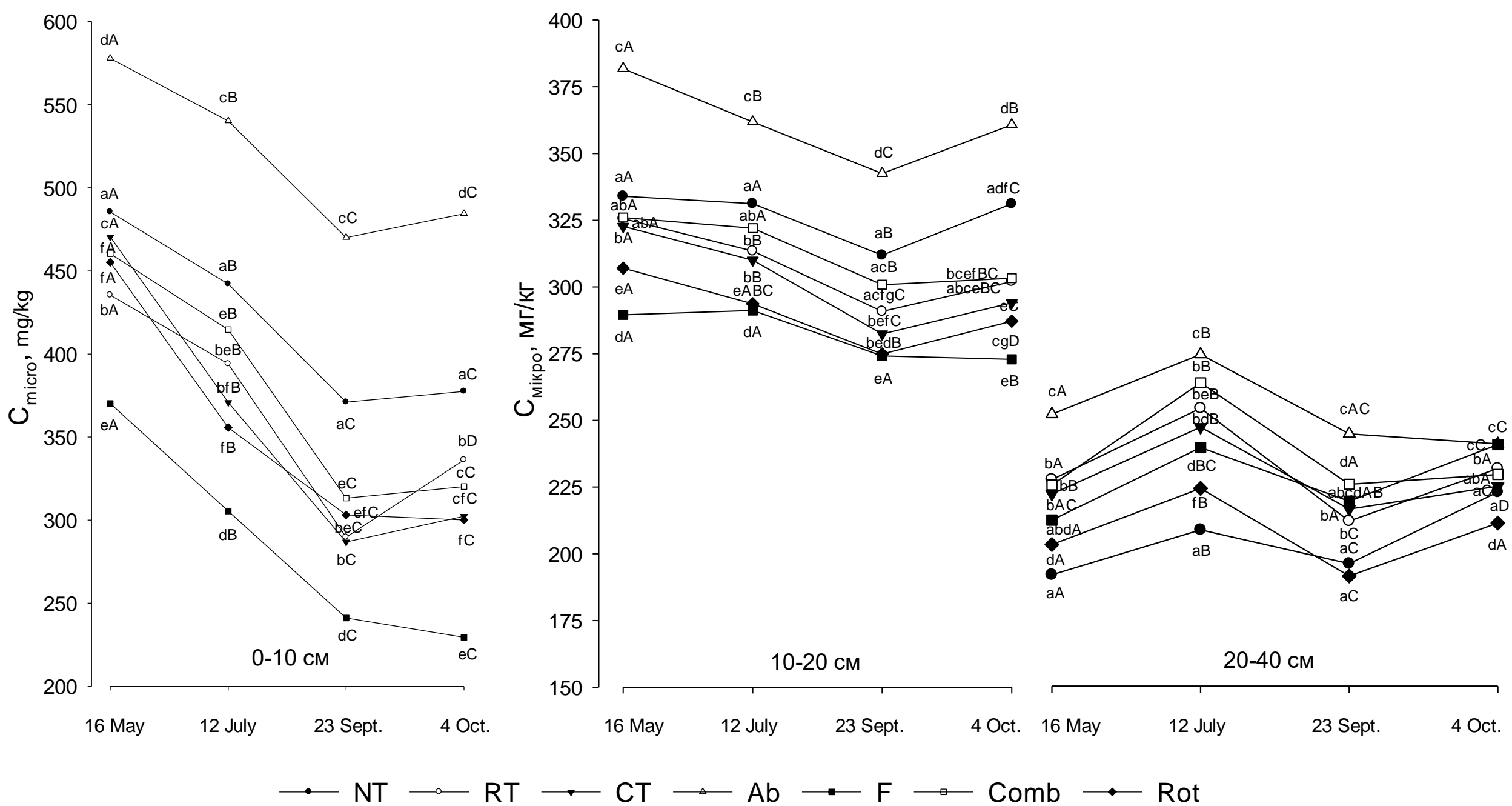

Fig. 2. Seasonal dynamics of $C_{\text {micro }}$ in 0-40 cm layer of isohumusol (Hailun) for 9 years of use: conservation tillage (CT), notill (NT), rotary (Rot), reduced (ridge) tillage (RT) and combined (Comb) tillage and fallow (F, 22 years) and abandoned field (Ab, 22 years). Average values with different lowercase letters indicate a significant difference between tillage options, uppercase letters - a significant difference between the selection periods (HIP, $\alpha=0,05$ ) 

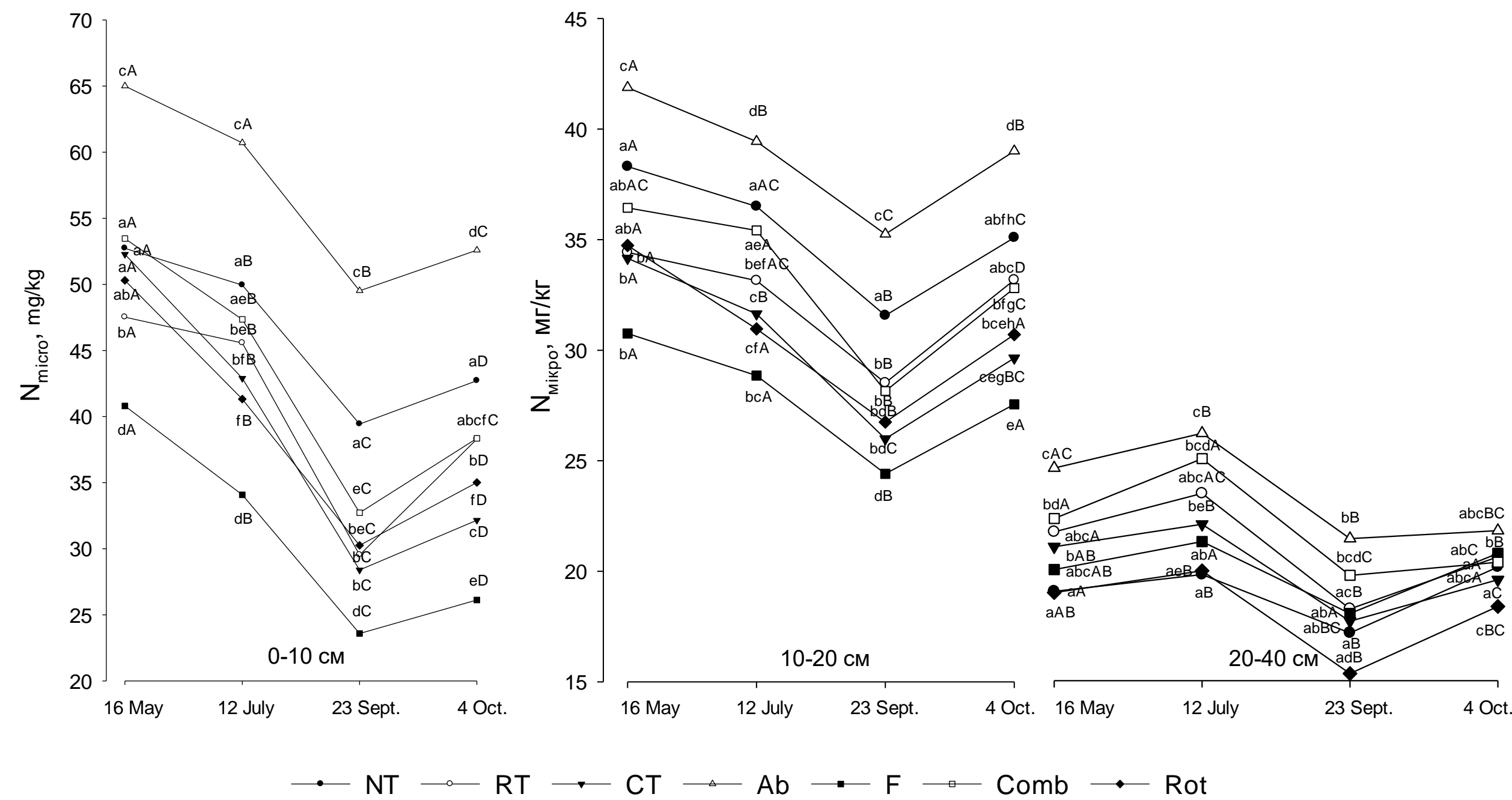

Fig. 3. Seasonal dynamics of $\mathrm{N}_{\text {micro }}$ in $0-40 \mathrm{~cm}$ layer of izogumusol (Hailun) for 9 years of use: conservation tillage (CT), notill (NT), rotary (Rot), reduced (ridge) tillage (RT) and combined (Comb) tillage and fallow (F, 22 years) and abandoned field $(\mathrm{Ab}, 22$ years). Average values with different lowercase letters indicate a significant difference between tillage options, uppercase letters - a significant difference between the selection periods (HIP, $\alpha=0,05$ ). 


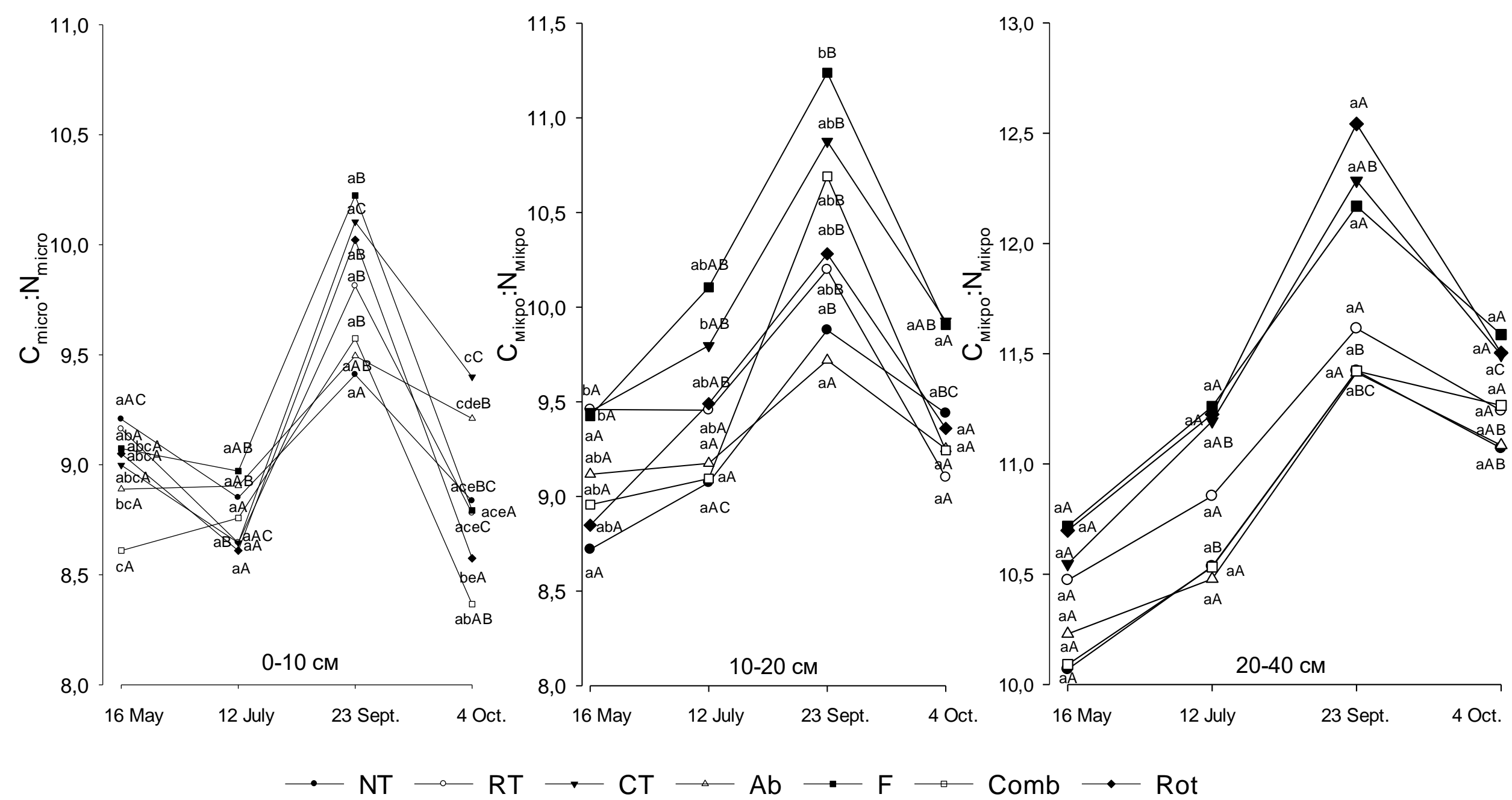

Fig. 4. Seasonal dynamics of $C_{\text {micro }}: \mathrm{N}_{\text {micro }}$ in 0-40 $\mathrm{cm}$ layer of izogumusol (Hailun) for 9 years of use: conservation tillage (CT), no-till (NT), rotary (Rot), reduced (ridge) tillage (RT) and combined (Comb) tillage and fallow (F, 22 years) and abandoned field ( $\mathrm{Ab}, 22$ years). Average values with different lowercase letters indicate a significant difference between tillage options, uppercase letters - a significant difference between the selection periods (HIP, $\alpha=0,05$ ). 

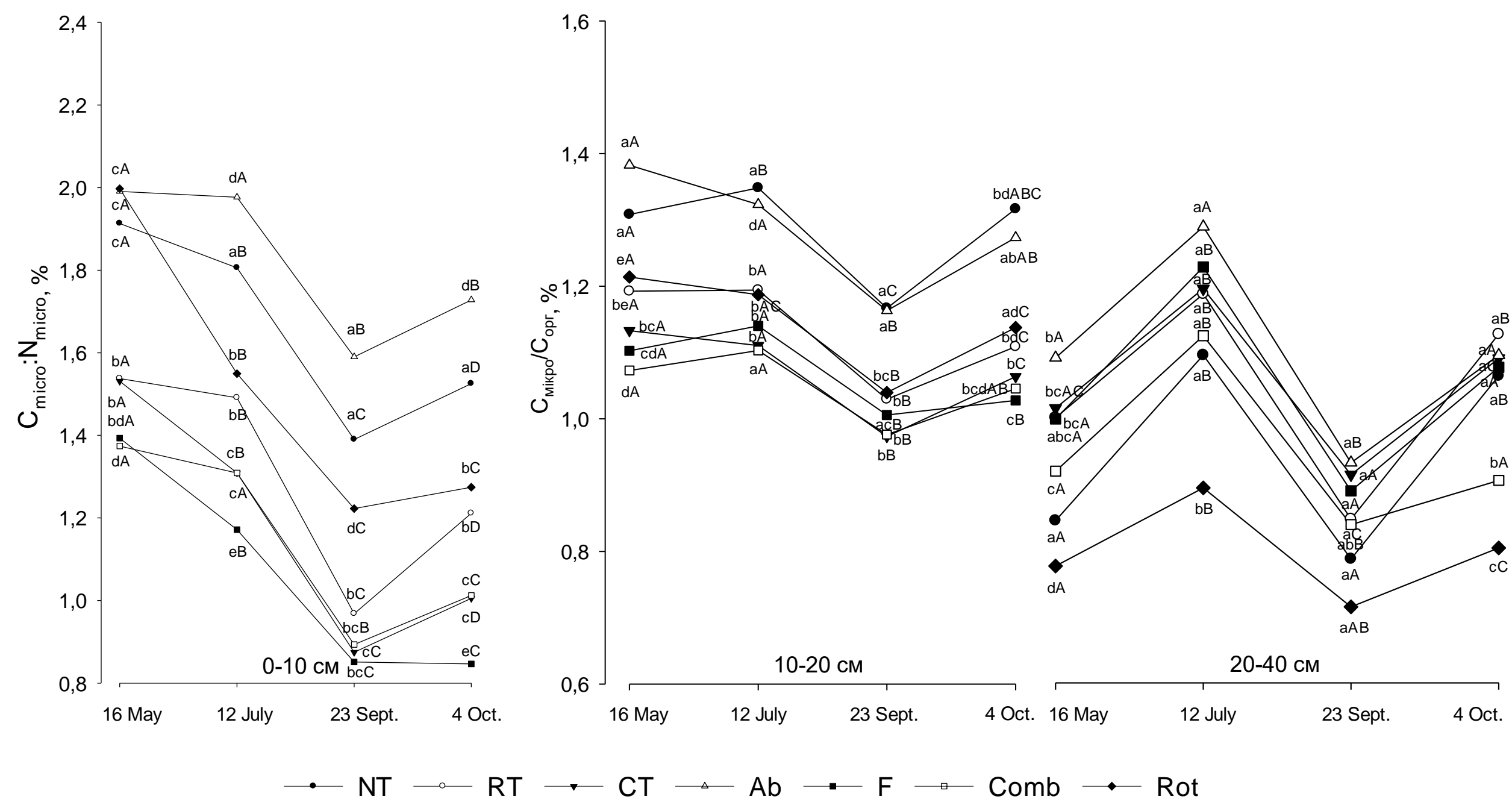

Fig. 5. Dynamics of the microbial index $\mathrm{C}_{\mathrm{micro}}: \mathrm{C}_{\mathrm{org}}, \%$ in $0-40 \mathrm{~cm}$ layer of isohumusol for 7 years of use: conservation tillage (CT), no-till (NT), rotary (Rot), reduced (ridge) tillage (RT) and combined (Comb) tillage and fallow (F, 22 years) and abandoned field ( $\mathrm{Ab}, 22$ years). Average values with different lowercase letters indicate a significant difference between tillage options, uppercase letters - a significant difference between the selection periods (HIP, $\alpha=0,05$ ). 
Table 1.

K. Pearson's linear correlation coefficients between $\mathbf{C}_{\text {micro }}$ and $\mathbf{C}_{\text {org }}$

\begin{tabular}{|c|c|c|c|c|c|c|c|}
\hline Parameters & NT $\mathrm{C}_{\text {org }}$ & RT $\mathrm{C}_{\text {org }}$ & $\mathrm{CT} \mathrm{C}_{\text {org }}$ & $\mathrm{Ab} \mathrm{C}_{\text {org }}$ & $\mathrm{F} \mathrm{C}_{\text {org }}$ & Comb $\mathrm{C}_{\text {org }}$ & Rot $\mathrm{C}_{\text {org }}$ \\
\hline \multicolumn{8}{|c|}{$0-10 \mathrm{~cm}$} \\
\hline NT $\mathrm{C}_{\text {micro }}$ & $-0,418$ & $-0,395$ & $-0,351$ & $-0,143$ & $-0,789$ & $-0,142$ & $-0,678$ \\
\hline$p$-value & 0,176 & 0,204 & 0,263 & 0,658 & 0,00231 & 0,659 & 0,0154 \\
\hline $\mathrm{RT} \mathrm{C}_{\text {micro }}$ & $-0,571$ & $-0,550$ & $-0,558$ & $-0,371$ & $-0,884$ & $-0,323$ & $-0,792$ \\
\hline$p$-value & 0,0526 & 0,0637 & 0,0593 & 0,235 & 0,000137 & 0,306 & 0,00213 \\
\hline CT $\mathrm{C}_{\text {micro }}$ & $-0,289$ & $-0,285$ & $-0,278$ & $-0,0686$ & $-0,757$ & $-0,0173$ & $-0,597$ \\
\hline$p$-value & 0,362 & 0,369 & 0,382 & 0,832 & 0,00437 & 0,958 & 0,0404 \\
\hline $\mathrm{Ab} \mathrm{C}_{\text {micro }}$ & $-0,463$ & $-0,437$ & $-0,393$ & $-0,201$ & $-0,797$ & $-0,186$ & $-0,701$ \\
\hline$p$-value & 0,129 & 0,155 & 0,207 & 0,532 & 0,00192 & 0,563 & 0,0111 \\
\hline $\mathrm{F} \mathrm{C}_{\text {micro }}$ & $-0,269$ & $-0,255$ & $-0,212$ & 0,00751 & $-0,700$ & 0,0125 & $-0,580$ \\
\hline$p$-value & 0,398 & 0,423 & 0,509 & 0,982 & 0,0112 & 0,969 & 0,0480 \\
\hline Comb $\mathrm{C}_{\text {micro }}$ & $-0,446$ & $-0,441$ & $-0,381$ & $-0,167$ & $-0,802$ & $-0,187$ & $-0,700$ \\
\hline$p$-value & 0,146 & 0,152 & 0,222 & 0,603 & 0,00170 & 0,562 & 0,0113 \\
\hline Rot $C_{\text {micro }}$ & $-0,177$ & $-0,165$ & $-0,158$ & 0,0506 & $-0,680$ & 0,103 & $-0,509$ \\
\hline$p$-value & 0,583 & 0,609 & 0,624 & 0,876 & 0,0150 & 0,751 & 0,0908 \\
\hline \multicolumn{8}{|c|}{$10-20 \mathrm{~cm}$} \\
\hline NT $\mathrm{C}_{\text {micro }}$ & $-0,697$ & $-0,664$ & $-0,708$ & $-0,604$ & $-0,877$ & $-0,787$ & $-0,731$ \\
\hline$p$-value & 0,0117 & 0,0184 & 0,0100 & 0,0376 & 0,000178 & 0,00238 & 0,00696 \\
\hline RT $\mathrm{C}_{\text {micro }}$ & $-0,229$ & $-0,405$ & $-0,324$ & $-0,157$ & $-0,636$ & $-0,630$ & $-0,654$ \\
\hline$p$-value & 0,473 & 0,192 & 0,305 & 0,626 & 0,0261 & 0,0282 & 0,0210 \\
\hline $\mathrm{CT} \mathrm{C}_{\text {micro }}$ & $-0,221$ & $-0,544$ & $-0,522$ & $-0,135$ & $-0,680$ & $-0,820$ & $-0,714$ \\
\hline$p$-value & 0,489 & 0,0676 & 0,0818 & 0,675 & 0,0149 & 0,00108 & 0,00905 \\
\hline $\mathrm{Ab} \mathrm{C}_{\text {micro }}$ & $-0,258$ & $-0,411$ & $-0,503$ & $-0,182$ & $-0,585$ & $-0,747$ & $-0,549$ \\
\hline$p$-value & 0,418 & 0,184 & 0,0952 & 0,571 & 0,0455 & 0,00522 & 0,0646 \\
\hline $\mathrm{F} \mathrm{C}_{\text {micro }}$ & $-0,0173$ & $-0,639$ & $-0,484$ & $-0,0712$ & $-0,609$ & $-0,758$ & $-0,780$ \\
\hline$p$-value & 0,957 & 0,0253 & 0,111 & 0,826 & 0,0354 & 0,00432 & 0,00278 \\
\hline Comb $\mathrm{C}_{\text {micro }}$ & $-0,169$ & $-0,482$ & $-0,268$ & $-0,0977$ & $-0,618$ & $-0,598$ & $-0,665$ \\
\hline$p$-value & 0,600 & 0,112 & 0,400 & 0,763 & 0,0321 & 0,0399 & 0,0182 \\
\hline Rot $\mathrm{C}_{\text {micro }}$ & $-0,312$ & $-0,479$ & $-0,425$ & $-0,148$ & $-0,622$ & $-0,736$ & $-0,552$ \\
\hline$p$-value & 0,323 & 0,116 & 0,169 & 0,646 & 0,0310 & 0,00634 & 0,0627 \\
\hline
\end{tabular}

Continuation of table 1.

\begin{tabular}{|c|c|c|c|c|c|c|c|}
\hline Parameters & NT $\mathrm{C}_{\text {org }}$ & $\mathrm{RT} \mathrm{C}_{\text {org }}$ & CT C $\mathrm{Corg}_{\text {. }}$ & $\mathrm{Ab} \mathrm{C_{ \text {org } }}$ & $\mathrm{F} \mathrm{C}_{\text {org }}$ & Comb $C_{\text {org }}$ & Rot $C_{\text {org }}$ \\
\hline \multicolumn{8}{|c|}{$20-40 \mathrm{~cm}$} \\
\hline NT $\mathrm{C}_{\text {micro }}$ & $-0,660$ & $-0,644$ & $-0,591$ & $-0,174$ & $-0,135$ & $-0,553$ & $-0,175$ \\
\hline$p$-value & 0,0194 & 0,0239 & 0,0429 & 0,589 & 0,675 & 0,0623 & 0,587 \\
\hline $\mathrm{RT} \mathrm{C}_{\text {micro }}$ & $-0,788$ & $-0,605$ & $-0,907$ & $-0,866$ & $-0,413$ & $-0,850$ & $-0,875$ \\
\hline$p$-value & 0,00231 & 0,0370 & 0,0000459 & 0,000268 & 0,182 & 0,000460 & 0,000196 \\
\hline $\mathrm{CT} \mathrm{C}_{\text {micro }}$ & $-0,654$ & $-0,492$ & $-0,859$ & $-0,798$ & $-0,358$ & $-0,735$ & $-0,824$ \\
\hline$p$-value & 0,0211 & 0,104 & 0,000349 & 0,00185 & 0,253 & 0,00648 & 0,000981 \\
\hline $\mathrm{Ab} \mathrm{C}$ micro & $-0,405$ & $-0,141$ & $-0,630$ & $-0,753$ & $-0,440$ & $-0,508$ & $-0,752$ \\
\hline$p$-value & 0,192 & 0,662 & 0,0282 & 0,00469 & 0,153 & 0,0916 & 0,00475 \\
\hline $\mathrm{F} \mathrm{C}_{\text {micro }}$ & $-0,615$ & $-0,703$ & $-0,682$ & $-0,308$ & $-0,0644$ & $-0,578$ & $-0,363$ \\
\hline$p$-value & 0,0334 & 0,0108 & 0,0146 & 0,330 & 0,842 & 0,0492 & 0,246 \\
\hline
\end{tabular}




\begin{tabular}{|c|c|c|c|c|c|c|c|}
\hline Comb $\mathrm{C}_{\text {micro }}$ & $-0,506$ & $-0,363$ & $-0,746$ & $-0,685$ & $-0,347$ & $-0,589$ & $-0,704$ \\
\hline$p$-value & 0,0933 & 0,246 & 0,00537 & 0,0139 & 0,269 & 0,0440 & 0,0106 \\
\hline Rot $\mathrm{C}_{\text {micro }}$ & $-0,865$ & $-0,671$ & $-0,942$ & $-0,845$ & $-0,424$ & $-0,871$ & $-0,836$ \\
\hline$p$-value & 0,000281 & 0,0170 & 0,00000464 & 0,000533 & 0,170 & 0,000222 & 0,000704 \\
\hline
\end{tabular}

